\title{
Kondisi Tanah Habitat Ulin (Eusideroxylon zwageri T \& B) di Prevab Taman Nasional Kutai Kabupaten Kutai Timur
}

\author{
Dian Triadiawarman ${ }^{1}$ \\ 1 Program Studi Agroteknologi STIPER Kutai Timur, Kalimantan Timur \\ Jalan Soekarno-Hatta, Sangatta, Kutai Timur, Kalimantan Timur, email: \\ diantriadi72@gmail.com
}

\begin{abstract}
The objectives of this research were to obtain information about soil condition. Prevab Kutai National Park has podzolic soil, soil color is between yellowish brown to yellowish dark brown; the texture is clay to dusty clay; the structure are rounded blocky and angular blocky; Bulk Density (BD) between 0.99 - $1.67 \mathrm{~g} / \mathrm{cm}^{3}$; soil pore between 37.05 $62.65 \%$; depth of solum $100-150 \mathrm{~cm}$; effective depth $30-100 \mathrm{~cm}$; available water content between 4.43 - 13.88\%; soil acidity between highly acid up to moderately acid (pH 4.6 - 5.8); Cation Exchange Capacity (CEC) between 0.99 - $5.17 \mathrm{me} / 100 \mathrm{~g}$ clay; base saturation (BS) between 8.16 - 42.57\%; $C$ between $0.04-0.27 \%$; $N$ between 0.37 - 2.68\%, P between 2.85 - 34.96 ppm; K between 0.06 - $0.22 \mathrm{cmol} / \mathrm{kg}$; Ca between 0.41 - $6.40 \mathrm{cmol} / \mathrm{kg} ; \mathrm{Mg}$ between $0.11-3.40 \mathrm{cmol} / \mathrm{kg}$. In order to preserve and to increase the ironwood potential, a cultivation activity should be undertaken in a suitable environment for growth, that is at an altitude of $0-400 \mathrm{~m}$ above sea level with a slopes of $0-100 \%$, on podzolic soil type, clay texture and sandy clay loam with very acid up to moderately acid soil.
\end{abstract}

Keywords: Ironwood, Eusideroxylon, soil, Prevab.

\begin{abstract}
ABSTRAK
Tujuan dari penelitian ini adalah untuk memperoleh informasi tentang kondisi tanah habitat ulin di Kawasan Prevab Taman Nasional Kutai Timur. Prevab Taman Nasional Kutai Timur memiliki tipe tanah Podsolik, dengan warna antara coklat kekuningan hingga coklat gelap kekuningan.. Tekstur tanah teridiri atas liat hingga liat berdebu. Struktur tanah berupa rounded blocky dan angular blocky. Bulk Density (BD) antara $0,99-1,67 \mathrm{~g} / \mathrm{cm}^{3}$. Porositas tanah antara $37,05-62,65 \%$. Kedalaman solum antara $100-150 \mathrm{~cm}$. Kedalaman efektif antara $30-100 \mathrm{~cm}$. Kapasitas ketersediaan air antara $4,43-13,88 \%$. Keasaman tanah berada pada tinggi hingga sedang $(\mathrm{pH} \mathrm{4,6-5,8)}$. Kapasitas Tukar Kation (KTK) antara 0,99-5,17 me/100 g. Base saturation (BS) antara $8,16-42,57 \%$. Kandungan $\mathrm{C}$ antara $0,04-0,27 \%, \mathrm{~N}$ antara $0,37-2,68 \%, \mathrm{P}$ antara 2.85 - $34.96 \mathrm{ppm}, \mathrm{K}$ antara $0,06-0,22 \mathrm{cmol} / \mathrm{kg}$, Ca antara $0,41-6,40 \mathrm{cmol} / \mathrm{kg}$, $\mathrm{Mg}$ antara $0,11-3,40 \mathrm{cmol} / \mathrm{kg}$. Untuk melindungi dan meningkatkan potensi tumbuh pohon ulin, kegiatan penanaman sebaiknya dilakukan pada kondisi lingkungan yang sesuai, yaitu pada daerah dengan ketinggian 0 - $400 \mathrm{~m}$ di atas permukaan laut dengan kemiringan antara $0-100 \%$, pada tipe tanah podsolik, dengan tekstur tanah liat dan sandy clay loam yang memiliki keasaman sangat tinggi hingga sedang.
\end{abstract}

Keywords: pohon ulin, Eusideroxylon, tanah, Prevab.

\section{Pendahuluan}

Tanah adalah salah satu faktor yang mempengaruhi pertumbuhan vegetasi. Karakteristik tanah yang spesifik akan mempengaruhi jenis-jenis vegetasi yang tumbuh di atasnya. Faktor-faktor tanah yang mempengaruhi pertumbuhan vegetasi menurut Kusnadi (2010), adalah sebagai berikut: Tekstur Tanah, Tingkat Kegemburan, Mineral Organik, Unsur Hara, Kandungan Air Tanah dan Kandungan Udara Tanah. Ulin (Eusideroxylon zwageri) sering disebut kayu besi karena sifat kayunya yang kuat dan awet, termasuk dalam famili Lauraceae, dengan nama lain ironwood (Inggris). Pohon ulin dapat mencapai 
ketinggian $35 \mathrm{~m}$ dengan tinggi bebas cabang $5-20 \mathrm{~m}$, diameter $100-150 \mathrm{~cm}$. Kulit luar berwarna coklat-kuning dan lambat laun menjadi coklat-hitam (Martawidjaya dkk., 1989).

Kawasan hutan Taman Nasional Kutai (TNK) merupakan salah satu contoh perwakilan hutan hujan dataran rendah di Kalimantan Timur. Berbagai macam tipe vegetasi tersebar di kawasan konservasi seluas 198.629 ha. TNK memiliki kekayaan jenis flora, fauna dan organisme lain yang tinggi. Terdapat sekitar 900 jenis tumbuhan di TNK yang telah teridentifikasi dan masih banyak lagi jenis tumbuhan yang belum diketahui. (Budiono, 2010). Penelitian ini bertujuan untuk memperoleh informasi kondisi tanah habitat ulin di Prevab TNK.

\section{Bahan dan Metode}

Bahan dan alat yang digunakan yaitu: tegakan ulin, peta kerja TNK, bor tanah, ring sampel, munshell soil card, clinometer, cangkul, skop, kompas, kantong plastik, kamera, meteran, phi band, parang, pisau, ph meter, tali dan spidol.

Penelitian lapangan dan laboraturium dilakukan pada bulan April- Juni 2013. Penelitian lapangan dilaksanakan pada habitat alami ulin di wilayah Prevab Taman Nasional Kutai Kabupaten Kutai Timur. Penelitian Laboraturium dilaksanakan di Laboraturium IImu Tanah Fakultas Kehutanan Universitas Mulawarman Samarinda.

Prosedur penelitian meliputi: pengumpulan data, orientasi lapangan, pembuatan petak penelitian, Pengambilan dan analisa data. Penelitian dilakukan dengan menggunakan metode deskriptif kuantitatif dan deskriptif kualitatif. Data morfologi tanah diperoleh melalui penggalian dan pemeriksaan profil tanah dalam petak-petak penelitian di setiap lokasi sebaran ulin. Kriteria penilaian sifat-sifat morfologi tanah mengacu kepada Petunjuk Teknis Pengamatan Tanah, Balai Penelitian Tanah - Departemen Pertanian (2004).

Pengolahan data sampel tanah (morfologi, komposit dan utuh) di setiap habitat ulin dilakukan berdasarkan Petunjuk Teknis Badan Penelitian dan Pengembangan Pertanian Departemen Pertanian (2004) guna mengetahui sifat fisik dan Petunjuk Teknis Balai Penelitian Tanah Departemen Pertanian (2005) untuk mengetahui sifat kimia tanah.

\section{Hasil Penelitian dan Pembahasan}

Dari segi geografis, Taman Nasional Kutai terletak di antara 07'54" - 0³3'53" LU

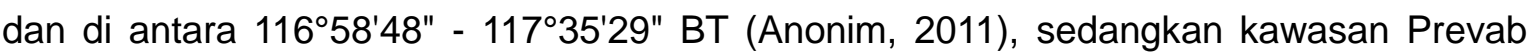
terletak di antara 117²7'53,154" BT dan 0³1'52,609" LU (Treisna, 2005).

Berdasarkan hasil pengolahan data Citra Satelit Tahun 2005, diperoleh informasi bahwa secara umum TNK memiliki topografi datar yang tersebar hampir di seluruh luas kawasan (92\%) dan topografi bergelombang hingga berbukit tersebar pada bagian tengah kawasan yang membentang arah utara dan selatan (8\%). Sebagian besar kawasan 
ISSN 2354-7251 (print)

memiliki ketinggian antara 1-100 m dpl (61\%) yang tersebar pada bagian timur dan barat. Tingkat ketinggian bagian tengah antara 100 - 250 m dpl (39\%) (Treisna, 2005).

Menurut Anonim (2011), berdasarkan peta Geologi Kalimantan Timur, formasi geologi kawasan ini sebagian besar meliputi tiga bagian, yaitu: Bagian pantai terdiri dari batuan sendimen alluvial induk dan terumbu karang; bagian tengah terdiri dari batuan miosen atas; dan bagian barat terdiri dari batuan sendimen bawah.

Keseluruhan petak-petak penelitian seperti ditunjukkan pada Gambar 1, memiliki jenis tanah yang sama, yaitu Podsolik Merah Kuning (Podsolik). Tanah-tanah Podsolik secara genetis ditandai dengan kehadiran horizon Argilik pada suatu kedalaman di horison B. Horison Argilik diberi simbol Bt. Kriteria horizon Argilik mengacu kepada Soil Survey Staff (1998).

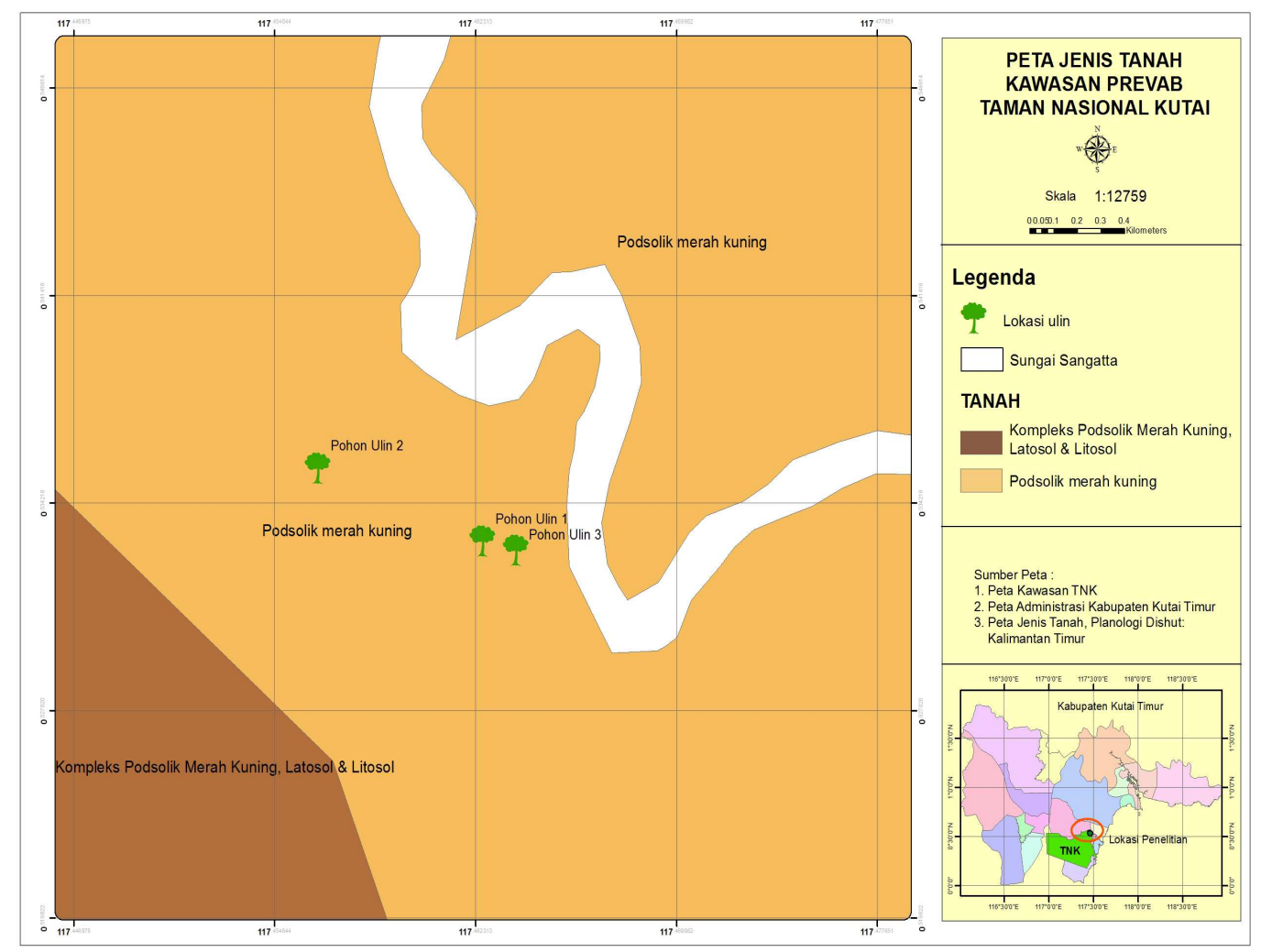

Gambar 1. Peta Jenis Tanah Lokasi Petak Penelitian Prevab TNK.

Pola perubahan vertikal lapisan-lapisan tanah Podsolik secara umum di petak penelitian terlihat memiliki kedalaman lapisan yang berbeda-beda. Menurut Hanafiah (2005), meskipun tanah terdiri dari beberapa horizon, namun bagi tanaman yang sangat penting adalah horizon $\mathrm{O}-\mathrm{A}$ (lapisan atas) yang biasanya mempunyai ketebalan di bawah $30 \mathrm{~cm}$. Kartasapoetra dan Mulyani (1987), menyatakan bahwa lapisan tanah atas (top soil) memiliki ketebalan solum sekitar 20 sampai $35 \mathrm{~cm}$.

Tekstur tanah Podsolik di petak-petak penelitian (Tabel 1), menunjukkan bahwa lapisan tanah I lempung berliat, liat berdebu dan lempung berdebu. Lapisan tanah II bertekstur lempung liat berdebu, liat berdebu dan lempung berdebu-lempung berliat. 
Lapisan tanah III liat, liat berdebu-lempung liat berdebu dan liat.

Struktur tanah berperan terhadap pertumbuhan tanaman melalui efek kelembapan dan aerasi yang ditimbulkan oleh kondisi ped. Pada petak penelitian, struktur tanah lapisan atas memperlihatkan kemiripan dengan struktur tanah lapisan bawah. Struktur lapisan atas adalah gumpal membulat, sedangkan pada lapisan bawah strukturnya gumpal bersudut. Perbedaan struktur tanah untuk setiap kedalaman tanah pada setiap petak penelitian merupakan gambaran bahwa tekstur tanah mempengaruhi pembentukan struktur tanah. Perkembangan struktur tanah yang lebih kuat terjadi pada tanah halus. Secara umum kondisi struktur tanah di petak penelitian bersifat baik. Hal ini sejalan dengan pendapat Hardjowigeno (2007), struktur tanah yang baik adalah yang bentuknya membulat sehingga tidak dapat saling bersinggungan dengan rapat. Akibatnya pori-pori tanah banyak terbentuk. Di samping itu struktur tanah tidak mudah rusak (mantap) sehingga pori-pori tanah tidak cepat tertutup bila terjadi hujan.

Pada Tabel 2 terlihat, bahwa nilai kerapatan lindak tanah cenderung makin dekat ke permukaan tanah, maka nilai kerapatan lindaknya makin rendah, atau dapat dinyatakan bahwa semakin jauh dari permukaan tanah, maka ruangan yang berisi air dan udara semakin sedikit dan ruangan yang berisi padatan semakin banyak. Hal ini menunjukkan bahwa kondisi aerasi yang semakin jelek pada lapisan yang lebih dalam, karena jumlah bahan organik dan jumlah pori-pori tanah yang semakin sedikit. Secara umum nilai kerapatan lindak di petak penelitian dapat dikatakan normal, karena pada umumnya kerapatan lindak tanah berkisar 1,1-1,6 g/ $\mathrm{cm}^{3}$ (Hardjowigeno, 2007).

Hasil pengukuran jumlah pori total tanah berdasarkan kelas tekstur tanah di petak penelitian ditampilkan pada Tabel 2. Pori-pori tanah di petak penelitian, dari lapisan atas ke lapisan di bawahnya persentase pori-pori semakin kecil. Kondisi ini dipengaruhi oleh kadar bahan organik serta aktivitas organisme mikro pada lapisan bawah intensitas kehadirannya semakin berkurang, sehingga pada lapisan bawah tidak gembur. Menurut Kusnadi (2010), bahwa kandungan udara di dalam tanah antara tanah di lahan tertentu dengan lahan lainnya berbeda-beda. Hal tersebut terjadi karena adanya tingkat kegemburan tanah yang berbeda-beda. Semakin tinggi tingkat kegemburan suatu tanah, semakin besar kandungan udara di dalam tanah. Kandungan udara di dalam tanah diperlukan tumbuhan dalam respirasi melalui sistem perakaran pada tumbuhan.

Kedalaman suatu tanah menggambarkan kadar bahan organik yang terakumulasi pada lapisan atas tanah. Kedalaman solum tanah di petak penelitian memiliki kedalaman yang beragam (Tabel 2). Kedalaman efektif tanah merupakan kedalaman tanah di mana akar dapat dijumpai dalam jumlah maksimal. Kedalaman efektif tanah sangat berperan terhadap pertumbuhan vegetasi melalui kemampuan jangkauan akar untuk menyerap unsur hara. Hal ini tidak berarti akar yang dapat berpenetrasi sangat dalam akan mampu 
memberikan pasokan unsur hara yang besar ke bagian atas tanaman. Kualitas dan kuantitas pasokan hara selain ditentukan oleh sifat fisiologi tanaman, juga dipengaruhi oleh jenis-jenis hara yang tersedia dan dibutuhkan oleh tanaman yang terdapat dalam kompleks jerapan, serta aktivitas berbagai organisme yang terdapat di sekitar tanaman dan di dalam tanah, yang dapat menghambat atau menstimulir penyerapan hara.

Air penting untuk pertumbuhan tanaman dan reaksi-reaksi kimia dalam pelapukan mineral. Air perkolasi membantu siklus unsur hara dan pemindahan liat, oksida besi dan aluminium, garam-garam dan lain-lain. Di daerah kering gerakan air ke atas (kapiler), menyebabkan terjadinya akumulasi garam di permukaan tanah. Hasil pengukuran kandungan air tanah di petak penelitian ditampilkan pada Tabel 2. Kondisi kadar air tersedia dalam tanah di petak penelitian, dari lapisan atas ke lapisan dibawahnya persentase kadar air semakin kecil. Kondisi ini dipengaruhi oleh tekstur dan bahan organik serta aktivitas organisme mikro pada solum bawah intensitas kehadirannya semakin berkurang. Kusnadi (2010) menyatakan, bahwa air yang terdapat di dalam tanah terutama air tanah permukaan dan air tanah dangkal merupakan salah satu unsur pokok bagi pertumbuhan dan perkembangan vegetasi.

Hasil pemeriksaan morfologi dan sifat fisik tanah Podsolik di petak-petak penelitian, ditunjukkan pada Tabel 1 dan 2.

Tabel 1. Ikhtisar Morfologi Tanah di Lokasi Penelitian.

\begin{tabular}{|c|c|c|c|c|c|c|c|c|}
\hline $\begin{array}{c}\text { Lokasi } \\
\text { Penelitian }\end{array}$ & Horizon & $\begin{array}{l}\text { Kedalaman } \\
(\mathrm{cm})\end{array}$ & Warna & $\begin{array}{c}\text { Batas } \\
\text { horizon }\end{array}$ & Struktur & Tekstur & Perakaran & $\begin{array}{l}\text { Fragmen } \\
\text { Batuan }\end{array}$ \\
\hline \multirow{6}{*}{ Ulin I } & $\mathrm{O}$ & $0-4$ & $\begin{array}{c}2,5 \mathrm{YR} \\
3 / 2\end{array}$ & c. w & $A B$ & CL & Kasar, banyak & - \\
\hline & $A_{1}$ & $4-12$ & $\begin{array}{c}2,5 \mathrm{YR} \\
4 / 4 \\
\end{array}$ & g. w & $A B$ & $\mathrm{SiCL}$ & Sedikit, sedang & - \\
\hline & $\mathrm{A}_{2}$ & $12-60$ & $\begin{array}{c}2,5 \mathrm{YR} \\
6 / 6 \\
\end{array}$ & g. w & $S A B$ & C & Sedikit, sedang & - \\
\hline & $\mathrm{B}_{1}$ & $60-120$ & 5 YR 6/6 & d. i & SAB & C & Sedikit, halus & Batuan sedikit \\
\hline & $\mathrm{B}_{2}$ & $120-150$ & $\begin{array}{c}7,5 \mathrm{YR} \\
7 / 6 \\
\end{array}$ & d. i & $S A B$ & C & Sedikit, halus & $\begin{array}{l}\text { Batuan } \\
\text { banyak }\end{array}$ \\
\hline & C & $>150$ & - & - & - & - & - & - \\
\hline \multirow{6}{*}{ Ulin II } & $\mathrm{O}$ & $0-4$ & $5 \mathrm{YR} 3 / 4$ & c. w & $A B$ & $\mathrm{SiC}$ & Kasar, banyak & - \\
\hline & $A_{1}$ & $4-10$ & 5 YR 4/4 & g. w & $A B$ & $\mathrm{SiC}$ & Kasar, banyak & - \\
\hline & $\mathrm{A}_{2}$ & $10-22$ & 5 YR 4/6 & g. w & $A B$ & $\mathrm{SiC}$ & Sedikit, sedang & Batuan sedikit \\
\hline & $\mathrm{B}_{1}$ & $22-45$ & $\begin{array}{c}7,5 \mathrm{YR} \\
5 / 6 \\
\end{array}$ & g. i & $S A B$ & C & Sedikit, halus & Batuan sedikit \\
\hline & $\mathrm{B}_{2}$ & $45-100$ & 5 YR 7/6 & g. i & $S A B$ & C & - & $\begin{array}{l}\text { Batuan } \\
\text { banyak }\end{array}$ \\
\hline & C & $>100$ & - & - & - & - & - & - \\
\hline \multirow{6}{*}{ Ulin III } & $\mathrm{O}$ & $0-3$ & 5 YR 4/4 & c. w & $A B$ & SiL & Kasar, banyak & - \\
\hline & $A_{1}$ & $3-10$ & 5 YR 6/4 & d. w & $A B$ & SiL & Sedikit, sedang & - \\
\hline & $\mathrm{A}_{2}$ & $10-35$ & 10 YR 4/4 & d. w & $A B$ & $C L$ & Sedikit, sedang & Batuan sedikit \\
\hline & $\mathrm{B}_{1}$ & $35-62$ & 10 YR 4/6 & d. w & $S A B$ & $\mathrm{C}$ & Sedikit, halus & Batuan sedikit \\
\hline & $\mathrm{B}_{2}$ & $62-140$ & 10 YR 4/6 & g. w & $S A B$ & $\mathrm{C}$ & - & $\begin{array}{l}\text { Batuan } \\
\text { banyak }\end{array}$ \\
\hline & C & $>140$ & - & - & - & - & - & - \\
\hline
\end{tabular}


Tabel 2. Ikhtisar Sifat-sifat Fisik Tanah di Lokasi Penelitian.

\begin{tabular}{|c|c|c|c|c|c|c|}
\hline $\begin{array}{l}\text { Lokasi } \\
\text { Penelitian }\end{array}$ & $\begin{array}{l}\text { Kedalaman } \\
\text { (cm) }\end{array}$ & $\begin{array}{c}\text { Kerapatan } \\
\text { Lindak }\left(\mathrm{g} / \mathrm{cm}^{3}\right)\end{array}$ & $\begin{array}{l}\text { Porisitas Total } \\
\text { Tanah (\%) }\end{array}$ & $\begin{array}{l}\text { Kedalaman } \\
\text { Solum }(\mathrm{cm})\end{array}$ & $\begin{array}{l}\text { Kedalaman } \\
\text { Efektif }(\mathrm{cm})\end{array}$ & $\begin{array}{c}\text { Kandungan } \\
\text { Air (\%) }\end{array}$ \\
\hline \multirow{4}{*}{ Ulin I } & $0-10$ & 1,25 & 52,65 & \multirow{4}{*}{150} & \multirow{4}{*}{$50-100$} & 11,26 \\
\hline & $10-20$ & 1,36 & 48,67 & & & 11,83 \\
\hline & $20-50$ & 1,50 & 43,52 & & & 8,00 \\
\hline & $50-100$ & 1,67 & 37,05 & & & 6,99 \\
\hline \multirow{4}{*}{ Ulin II } & $0-10$ & 0,99 & 62,65 & \multirow{4}{*}{100} & \multirow{4}{*}{$50-100$} & 13,88 \\
\hline & $10-20$ & 1,27 & 52,11 & & & 4,43 \\
\hline & $20-50$ & 1,37 & 48,33 & & & 4,62 \\
\hline & $50-100$ & 1,56 & 40,96 & & & 1,57 \\
\hline \multirow{4}{*}{ Ulin III } & $0-10$ & 1,37 & 48,34 & \multirow{4}{*}{140} & \multirow{4}{*}{$30-50$} & 11,67 \\
\hline & $10-20$ & 1,41 & 46,77 & & & 12,11 \\
\hline & $20-50$ & 1,41 & 46,61 & & & 8,34 \\
\hline & $50-100$ & 1,53 & 42,16 & & & 6,02 \\
\hline
\end{tabular}

Komponen kimia tanah memiliki peran terbesar dalam menentukan sifat dan ciri tanah umumnya dan kesuburan tanah pada khususnya. Sifat-sifat kimia tanah yang penting antara lain Kapasitas Tukar Kation (KTK), Kejenuhan Basa (KB), reaksi tanah (pH), dan unsur-unsur hara.

Tabel 3. Kisaran Nilai KTK (me/100 g) Liat dan KB (\%) Pada Petak Penelitian

\begin{tabular}{|c|c|c|c|}
\hline $\begin{array}{c}\text { Petak } \\
\text { penelitian }\end{array}$ & $\begin{array}{c}\text { Kelas kedalaman tanah } \\
(\mathrm{cm})\end{array}$ & KTK $(\mathrm{me} / 100 \mathrm{~g})$ Liat & Nilai Kejenuhan Basa (\%) \\
\hline \multirow{4}{*}{ Ulin I } & $0-10$ & 2,43 & 40,55 \\
\cline { 2 - 4 } & $10-20$ & 2,96 & 25,82 \\
\cline { 2 - 4 } & $20-40$ & 2,82 & 14,03 \\
\cline { 2 - 4 } & $40-60$ & 4,16 & 12,31 \\
\hline \multirow{4}{*}{ Ulin II } & $60-100$ & 4,72 & 8,16 \\
\cline { 2 - 4 } & $0-10$ & 4,06 & 42,57 \\
\cline { 2 - 4 } & $10-20$ & 4,29 & 20,39 \\
\cline { 2 - 4 } & $20-40$ & 3,65 & 21,87 \\
\hline \multirow{4}{*}{ Ulin III } & $40-60$ & 5,17 & 16,03 \\
\cline { 2 - 4 } & $60-100$ & 1,74 & 42,04 \\
\cline { 2 - 4 } & $0-10$ & 0,99 & 34,78 \\
\cline { 2 - 4 } & $10-20$ & 2,14 & 25,15 \\
\cline { 2 - 4 } & $20-40$ & 3,34 & 12,16 \\
\hline
\end{tabular}

Tabel 3 menunjukkan bahwa tanah podsolik pada petak penelitian sebaran ulin mempunyai KTK rendah dengan nilai berkisar 0,99-5,17 dan mempunyai tekstur dengan kandungan liat lebih banyak dari kandungan pasir atau debu yaitu berkisar 17,75-74,85\%. Nilai KTK secara vertikal di petak penelitian memiliki kecenderungan semakin tinggi pada kedalaman yang semakin menjauhi lapisan permukaan tanah (Ulin I dan III), sedangkan Ulin II memiliki kecenderungan semakin tinggi dan menurun pada kedalaman yang 
semakin menjauhi lapisan permukaan tanah. Hal ini terjadi karena pada Ulin I dan III kandungan liatnya cukup tinggi. Hakim dkk, (1986) menyatakan, besarnya KTK tanah dipengaruhi oleh sifat dan ciri tanah itu sendiri yang antara lain adalah: $\mathrm{pH}$ tanah, tekstur tanah atau jumlah liat, jenis mineral liat, bahan organik dan pengapuran/ pemupukan.

Nilai Kejenuhan Basa yang terdapat di petak penelitian menunjukkan nilai tertinggi pada kelas kedalaman $0-10 \mathrm{~cm}$ (Tabel 3). Hal ini menunjukkan bahwa kadar liat mempengaruhi secara tidak langsung nilai Kejenuhan Basa. Kejenuhan Basa suatu tanah sangat dipengaruhi oleh iklim (curah hujan) dan pH tanah (Hakim dkk., 1986). Secara vertikal pola penyebaran nilai Kejenuhan Basa yang terdapat di petak penelitian menunjukkan kecenderungan menurun dari kedalaman tanah $0-10 \mathrm{~cm}$ sampai dengan kedalaman 60 - $100 \mathrm{~cm}$ yang merupakan horizon penimbunan hasil pencucian dari lapisan di atasnya.

Tabel 4. Kisaran nilai $\mathrm{pH} \mathrm{H}_{2} \mathrm{O}, \mathrm{pH} K C L, \mathrm{C}, \mathrm{N}, \mathrm{P}, \mathrm{K}, \mathrm{Ca}$ dan $\mathrm{Mg}$ pada petak penelitian.

\begin{tabular}{|c|c|c|c|c|c|c|c|c|c|}
\hline $\begin{array}{c}\text { Petak } \\
\text { penelitian }\end{array}$ & $\begin{array}{c}\text { Kelas } \\
\text { kedalaman } \\
\text { tanah }(\mathrm{cm})\end{array}$ & $\begin{array}{c}\mathrm{pH} \\
\mathrm{H} 2 \mathrm{O}\end{array}$ & $\begin{array}{c}\mathrm{pH} \\
\mathrm{KCL}\end{array}$ & $\mathrm{C}(\%)$ & $\mathrm{N}(\%)$ & $\mathrm{P}(\mathrm{ppm})$ & $\begin{array}{c}\mathrm{K} \\
(\mathrm{cmol} / \mathrm{kg})\end{array}$ & $\begin{array}{c}\mathrm{Ca} \\
(\mathrm{cmol} / \mathrm{kg})\end{array}$ & $\begin{array}{c}\mathrm{Mg} \\
(\mathrm{cmol} / \mathrm{kg})\end{array}$ \\
\hline \multirow{4}{*}{ Ulin I } & $0-10$ & 5,8 & 4,6 & 0,26 & 2,47 & 6,42 & 0,22 & 6,4 & 3,4 \\
\cline { 2 - 10 } & $10-20$ & 5,5 & 4,4 & 0,08 & 0,68 & 8,56 & 0,08 & 0,68 & 0,45 \\
\cline { 2 - 10 } & $20-50$ & 5,2 & 4,2 & 0,07 & 0,68 & 12,13 & 0,08 & 0,41 & 0,47 \\
\cline { 2 - 9 } & $50-100$ & 5,3 & 4,2 & 0,04 & 0,43 & 34,96 & 0,07 & 1,22 & 0,21 \\
\hline \multirow{4}{*}{ Ulin II } & $0-10$ & 5,5 & 4,3 & 0,27 & 2,68 & 12,13 & 0,19 & 1,47 & 1,73 \\
\cline { 2 - 9 } & $10-20$ & 5,5 & 4,3 & 0,13 & 1,15 & 4,99 & 0,14 & 0,81 & 1,14 \\
\cline { 2 - 9 } & $20-50$ & 5,5 & 4,2 & 0,09 & 0,56 & 19,98 & 0,11 & 0,75 & 1,11 \\
\cline { 2 - 9 } & $50-100$ & 5,2 & 4,2 & 0,06 & 0,37 & 21,41 & 0,11 & 0,69 & 0,87 \\
\hline \multirow{4}{*}{ Ulin III } & $0-10$ & 4,6 & 4,2 & 0,10 & 1,12 & 2,85 & 0,10 & 1,17 & 0,28 \\
\cline { 2 - 9 } & $10-20$ & 4,9 & 4,3 & 0,06 & 0,73 & 8,55 & 0,06 & 1,07 & 0,23 \\
\cline { 2 - 9 } & $20-50$ & 4,9 & 4,3 & 0,4 & 0,37 & 12,84 & 0,07 & 1,12 & 0,18 \\
\cline { 2 - 9 } & $50-100$ & 5,1 & 4,0 & 0,4 & 0,36 & 17,85 & 0,17 & 1,23 & 0,11 \\
\hline
\end{tabular}

Berdasarkan data Tabel 4 diperoleh informasi bahwa nilai $\mathrm{pH} \mathrm{H}_{2} \mathrm{O}$ tertinggi pada Ulin I (kedalaman 0 - $10 \mathrm{~cm}$ ), Ulin II (kedalaman 0 - $10 \mathrm{~cm}, 10-20 \mathrm{~cm}$ dan $20-50 \mathrm{~cm}$ ) dan Ulin III (kedalaman $50-100 \mathrm{~cm}$ ). Hal ini menunjukkan bahwa tingkat kedalaman tanah tidak berhubungan dengan $\mathrm{pH} \mathrm{H}_{2} \mathrm{O}$, melainkan berhubungan dengan faktor-faktor lain secara simultan, seperti KB, sifat misel (unit kristal liat) dan kation yang terjerap (Hakim dkk, 1986). Secara umum nilai $\mathrm{pH} \mathrm{H}_{2} \mathrm{O}$ lebih tinggi daripada nilai $\mathrm{pH} \mathrm{KCL}$. Hardjowigeno (1995) menyatakan, bahwa umumnya nilai pH KCL di daerah tropis lebih rendah daripada nilai $\mathrm{pH} \mathrm{H}_{2} \mathrm{O}$. Hal ini disebabkan bahwa di daerah tropis tingkat pencucian (Leaching) cukup tinggi akibat tingginya jeluk hujan sepanjang tahun, sehingga menyebabkan ion $\mathrm{Al}^{3+}$ mengusir ion-ion basa. Hilangnya ion-ion basa dari permukaan kompleks jerapan akan menyebabkan $\mathrm{pH} \mathrm{H}_{2} \mathrm{O}$ lebih tinggi daripada $\mathrm{pH} \mathrm{KCL}$ tanah.

Pola penyebaran konsentrasi $\mathrm{C}$ yang terdapat pada petak penelitian menunjukkan kecenderungan yang sama, yaitu konsentrasi $C$ tinggi pada lapisan $0-10 \mathrm{~cm}$, dan menurun mulai pada lapisan $10-20 \mathrm{~cm}$, kemudian menurun secara perlahan pada lapisan-lapisan berikutnya. Hal ini sejalan dengan penurunan $\mathrm{pH}$ pada lapisan tanah yang 
semakin jauh dari permukaan tanah karena pada lapisan tersebut bahan organik sangat sulit terurai. Veneklaas (1991) menyatakan, bahwa dekomposisi bahan organik sulit berlangsung sehingga bahan-bahan organik yang terdapat di tanah menjadi sulit terurai dan menimbulkan pengaruh masam yang tinggi.

Pola penyebaran nitrogen secara vertikal memiliki kecenderungan yang sama dengan unsur $\mathrm{C}$, yaitu tinggi di lapisan atas dan menurun secara drastis pada lapisan-lapisan berikutnya. Hal ini menunjukkan bahwa rendahnya $\mathrm{N}$ pada lapisan bawah karena sangat miskin kandungan bahan organik dan $\mathrm{N}$ dalam tanah bersifat mobil/tidak stabil. Winarso (2005) menyatakan, bahwa keberadaan $\mathrm{N}$ dalam tanah bersifat mobil, sehingga keberadaan $\mathrm{N}$ di dalam tanah cepat berubah atau bahkan hilang.

Konsentrasi $\mathrm{P}$ yang terdapat pada tanah-tanah podsolik di petak penelitian menunjukkan pola penyebaran dengan kecenderungan yang sama. Konsentrasi $P$ pada kedalaman tanah $0-10 \mathrm{~cm}$ (Ulin I) cukup rendah kemudian meningkat pada lapisan $10-$ $20 \mathrm{~cm}$, selanjutnya semakin meningkat pada lapisan $20-50 \mathrm{~cm}$ dan lapisan $50-100 \mathrm{~cm}$. Kondisi ini menunjukkan terjadi mobilisasi bahan organik pada tiap lapisan tanah. Transfer bahan organik dalam lapisan tanah dipengaruhi oleh pergerakan air ke bawah atau karena kegiatan binatang tanah. Rendahnya konsentrasi $\mathrm{P}$ erat hubungannya dengan nilai $\mathrm{pH}$, sehingga tidak memungkinkan fosfor tersedia dalam jumlah tinggi. Dampak $\mathrm{pH}$ terhadap ketersediaan fosfor ditentukan oleh adanya kation-kation lain. Pada lokasi penelitian $\mathrm{pH}$ tanah berkisar antara 4,6 - 5,8. Pada tanah masam, Fe dan Al akan larut. Hal ini disebabkan pada larutan tanah dengan $\mathrm{pH}$ rendah akan terbentuk ion $\mathrm{H}_{2} \mathrm{PO}_{4}$. Menurut Soepardi (1983), $\mathrm{pH}$ tanah yang harus dipertahankan agar $\mathrm{P}$ tersedia dalam jumlah maksimum adalah $\mathrm{pH} 6-7$.

Konsentrasi $\mathrm{K}$ dalam tanah dipengaruhi oleh $\mathrm{KTK}, \mathrm{KB}, \mathrm{pH}$ tanah, bahan organik dan tipe koloid. Pada tanah-tanah halus cenderung bahan organik tersedia lebih banyak dibandingkan tanah-tanah kasar, sehingga KTK pada tanah-tanah halus relatif tinggi. KTK yang tinggi memungkinkan lebih banyak kation-kation basa yang dapat dijerap, di antaranya ion $\mathrm{K}^{+}$. Bahan organik memiliki KTK yang tinggi sehingga bahan organik banyak mengandung unsur $\mathrm{K}$ selain unsur-unsur basa lainnya yang dapat dipertukarkan. Hal ini sejalan dengan hasil penelitian Sudarsono (1996) yang mengemukakan, bahwa bahan organik selain mengandung unsur-unsur $\mathrm{C}, \mathrm{H}$ dan $\mathrm{O}$ juga mengandung unsur-unsur $\mathrm{N}, \mathrm{P}$, $\mathrm{K}$, Ca, Mg dan S. Konsentrasi $\mathrm{K}$ yang terdapat di petak penelitian secara vertikal menunjukkan pola penyebaran dengan kecenderungan yang sama, yaitu tinggi pada lapisan top soil dan pada lapisan yang lebih dalam, nilainya semakin rendah.

Salah satu parameter yang penting dalam menduga tingkat kesuburan kimia tanah adalah kalsium $(\mathrm{Ca})$. Berdasarkan kelas kedalaman tanah, kisaran nilai konsentrasi $\mathrm{Ca}$ tertinggi pada kedalaman $0-10 \mathrm{~cm}$. Pola penyebaran konsentrasi Ca menunjukkan 
kecenderungan yang relatif sama, yaitu tinggi di lapisan atas dan menurun secara bertahap pada kedalaman-kedalaman berikutnya kemudian naik lagi pada kedalaman 50 $100 \mathrm{~cm}$. Fenomena ini menunjukkan bahwa sumber $\mathrm{Ca}$ di petak penelitian tidak hanya berasal dari batuan induk melainkan juga berasal dari air yang mengalir banyak membawa bahan organik (kapur larut di dalamnya) yang terdapat di permukaan tanah.

Seperti halnya kalsium, maka magnesium selalu dihubungkan dengan kemasaman tanah, karena ionnya dapat mengurangi efek kemasaman tanah. Dalam hal ini $\mathrm{Mg}$ berperan dapat menggantikan kedudukan ion hidrogen dari kompleks adsorpsi (Hakim dkk.,1986). Berdasarkan kelas kedalaman tanah (Tabel 4) terdapat kecenderungan bahwa semakin dekat dengan lapisan permukaan tanah maka konsentrasi Mg akan semakin tinggi. Kisaran konsentrasi Mg tertinggi diperoleh pada tanah dengan kelas kedalaman 0 $10 \mathrm{~cm}$. Ketersediaan Mg dapat terjadi akibat proses pelapukan dari mineral-mineral yang mengandung Mg. Selanjutnya, akibat proses tadi maka Mg akan bebas di dalam larutan tanah. Keadaan ini akan menyebabkan: (a) Mg hilang bersama air perkolasi, (b) Mg diserap oleh tanaman atau organisme hidup lainnya, (c) diabsorpsi oleh partikel liat dan (d) diendapkan menjadi mineral sekunder (Hakim dkk., 1986).

\section{Kesimpulan}

Kawasan Prevab Taman Nasional Kutai memiliki luas 2.500 ha, jenis tanah pada petak penelitian adalah tanah Podsolik Merah Kuning (Podsolik). Sifat fisik tanah pada petak penelitian yaitu: warna tanah antara Coklat Kekuningan-Coklat Kekuningan Gelap; tekstur liat-liat lempung berdebu; struktur gumpal membulat dan gumpal bersudut; BD antara 0,99 - 1,67 g/ $/ \mathrm{cm}^{3}$; pori tanah antara 37,05 - 62,65\%; kedalaman solum $100-150 \mathrm{~cm}$; kedalaman efektif 30 - $100 \mathrm{~cm}$; kadar air tersedia antara 4,43-13,88\%. Sifat kimia tanah pada petak penelitian yaitu: kemasaman tanah antara sangat asam sampai cukup asam (pH 4,6 - 5,8); KTK antara 0,99 - 5,17 me/100 g liat; KB antara 8,16 - 42,57\%; C antara $0,04-0,27 \% ; N$ antara 0,37 - 2,68\%; P antara 2,85 - 34,96 ppm; $\mathrm{K}$ antara 0,06 - 0,22 $\mathrm{cmol} / \mathrm{kg}$; Ca antara 0,41-6,40 cmol/kg; Mg antara 0,11 - 3,40 cmol/kg.

\section{Saran}

Dalam rangka pelestarian ulin sebaiknya kegiatan penanaman dilakukan pada lingkungan yang sesuai, yaitu pada ketinggian 0 - $400 \mathrm{~m}$ dpl dengan kelerengan tempat sebesar 0 - 100\%, jenis tanah Podsolik Merah Kuning (Podsolik), tekstur tanah liat dan liat lempung berpasir dengan kemasaman tanah kategori sangat masam sampai cukup masam. 


\section{Daftar Pustaka}

Anonim. (1998). Keys to Soil Taxonomy. ( $8^{\text {th }}$ ed.). Soil Survey Staff. USDA-NCRS: Washington, DC.

Anonim. (2004). Petunjuk Teknis Pengamatan Tanah. Balai Penelitian Tanah, Departemen Pertanian: Jakarta.

Anonim. (2005). Petunjuk Teknis Analisis Kimia Tanah, Tanaman, Air dan Pupuk. Balai Penelitian Tanah, Departemen Pertanian: Jakarta.

Anonim. (2006). Petunjuk Teknis Sifat Fisik Tanah dan Metode Analisisnya. Badan Penelitian dan Pengembangan Pertanian. Departemen Pertanian. Jakarta.

Anonim. (2011). Taman Kasional Kutai. http://www.tnkutai.com/index.php/in/biodiversitas/flora. (24 Jan 2012).

Budiono, A. (2010). TN Kutai Pesona Hutan Hujan Tropis Dataran Rendah Kalimantan Timur. Booklet Balai TN Kutai. Kalimantan Timur.

Hakim, N; Nyakpa, M. Y.; Lubis, A. M; Nugroho, S. G; Saul, M. R; Diha, M. A; Hong, G. B; Bailey, H.H. (1986). Dasar-Dasar Ilmu Tanah. Universitas Lampung: Lampung.

Hanafiah, K.A. (2005). Dasar-dasar IImu Tanah. Divisi Buku Perguruan Tinggi, PT Raja Grafindo Persada: Jakarta.

Hardjowigeno, S. (1995). IImu Tanah.(Edisi I). Akademika Pressindo: Jakarta.

Hardjowigeno, S. (2007). IImu Tanah. (Edisi Baru). Akademika Pressindo. :Jakarta.

Kartasapoetra dan S. Mulyani. (1987). Pengantar IImu Tanah. Rineka Cipta: Jakarta.

Kusnadi, R. (2010). Faktor Yang Mempengaruhi Kehidupan Makhluk Hidup. http://rahmatkusnadi6.blogspot.com/2010/09/faktor-yang-mempengaruhi-kehidupa n.html. (10 Jan 2012)

Martawidjaya, A.; I. Kartasujana; Y.I. Mandang; S.A. Prawira dan K. Kadir. (1989). Atlas Kayu Indonesia Jilid II. Badan Penelitian dan Pengembangan Kehutanan. Departemen Kehutanan: Jakarta.

Soepardi, G. (1983). Sifat dan Ciri Tanah. Institut Pertanian Bogor: Bogor.

Sudarsono. (1996). Genesis Tanah, Bahan Kuliah Program Studi Ilmu Tanah. Program Pascasarjana, Institut Pertanian Bogor: Bogor.

Treisna. (2005). Data Dasar Taman Nasional Kutai. Balai Taman Nasional Kutai: Bontang.

Veneklaas, E.J. (1991). Litterfall and Nutrient Fluxes in Two Montane Rain. Journal of Tropical Ecology.

Winarso, S. (2005). Kesuburan Tanah, Dasar Kesehatan dan Kualitas Tanah. Gava Media: Yogyakarta. 